\title{
Den nya generationens svek
}

\author{
Modernismens självrannsakan och Hagar Olssons essäer vid \\ tiderna kring två världskrig
}

Hagar Olsson (I893-I978) Är välKäND som en av de viktigaste introduktörerna av litterär modernism i ett finlandssvenskt sammanhang. Efter författardebuten I9I6 etablerade hon sig under en omvälvande tid som en tongivande deltagare i det kulturella samtalet. ${ }^{1}$ Särskilt uppmärksammat är hennes modernistiska "systerskap" med Edith Södergran. ${ }^{2}$ Man kan knappast överskatta den betydelse Olssons gärning som kritiker hade för modernismens spridning. Genom samarbeten med bland andra Elmer Diktonius stod hon bakom de kulturradikala och internationellt inriktade tidskrifterna Ultra (I922) och Quosego (I928-I929). ${ }^{3}$ Men trots att Olsson kanonise-

I. Roger Holmström, Karakteristik och värdering. Studier i finlandssvensk litteraturkritik I9I6-I929, Åbo: Åbo Akademis förlag 1988, s. I63-20I.

2. Agneta Rahikainen, Poeten och hennes apostlar. En biomytografisk analys av Edith Södergranbilden, Helsingfors: Helsingfors universitet 20I4, t.ex. s. 189-204; Birgitta Svanberg, "Med ansvar för hela mänskligheten. Om Hagar Olsson", Elisabeth Møller Jensen (red.), Nordisk kvinnolitteraturhistoria. Vida världen I9oo-I960, Bd 3 , Höganäs: Bra Böcker I996, s. 225-232; Ebba Witt-Brattström, Ediths jag. Edith Södergran och modernismens födelse, Stockholm: Norstedts 20II [I997], s. 255-3II. Systerskapet har ibland tenderat att överskugga Olssons egen insats som författare. Se Roger Holmström, "Skuggan av det eviga avskedet. Tankar kring Hagar Olssons Södergranuppfattning", George C. Schoolfield \& Laurie Thompson (eds.), Two Women Writers from Finland. Edith Södergran (1892-1923) and Hagar Olsson (1893-1978), Edinburgh: Lockharton Press 1995, s. 133 och Rahikainen, Poeten och hennes apostlar, s. 203.

3. Se t.ex. Johan Wrede,"Den finlandssvenska modernismens genombrott. En studie i idéernas sociala dynamik", Sven Linnér (red.), Från dagdrivare till feminister. Studier i finlandssvensk Igoo-talslitteratur, Skrifter utgivna av Svenska litteratursällskapet i Finland (SSLS) 537, Helsingfors: SLS I986, s. 4I-69 och Clas Zilliacus, "Världsherraväldets lokalvisor. Ultra, Quosego och andra handlingar från modernismens 
rats som författare var hennes verk länge relativt okända och outforskade. ${ }^{4}$

Under senare decennier har dock ett allt livligare forskningsfält vuxit fram. Som exempel från de senaste åren kan nämnas Judith Meurer-Bongardts avhandling från 20II som jag refererar till i artikeln; i skrivande stund är också en ny avhandling av Eva Kuhlefelt under utgivning, Dekadens och queer i Hagar Olssons tidiga prosa (utkommer hösten 2018). Roger Holmström, som stått för en viktig insats med två biografiska volymer, har menat att modernismens brytningstid, när Olsson var som mest aktiv, försatte "gängse författar- och kritikerkonstellationer i våldsam omprövning", liksom att författaren särskilt ställs på prov i "tider av krig och genomgripande sociala omvälvningar". ${ }^{5}$ Detta reflekteras i Olssons texter, särskilt som hon ofta introducerade nya författarskap men också formulerade kritiska inlägg i pågående kulturdebatter. Holmström menar att hon "genomgående" och "instinktivt" tog avstånd från den estetiska hållning som har kallats l'art pour l'art. ${ }^{6}$ Att Olsson föredrog ett mer engagerat författarideal står utom tvivel. Men det är viktigt att inte reducera hennes avståndstagande från l'art pour l'art till något rent "instinktivt", utan att visa hur hennes hållning utvecklades mot en fond av omvälvande samhällsförändringar. Detta gör också Holmström genom att uppmärksamma ett skiftande litterärt fokus och idéengagemang i Hagar Olssons författarskap över tid, samt en "förskjutning" i hennes förhållningssätt till den litterära modernismen (här förstådd som en avantgardistisk, formexperimenterande del av en vidare traditions- och normbrytande samt framtidsfokuserad kulturrörelse; denna modernism fick sitt stora genombrott i ett finlandssvenskt

I920-tal", Lisen Sundqvist (red.), Ultra och Quosego. Faksimilutgåva, Helsingfors: SLS/Stockholm: Atlantis 20I4, s. ix-xxvii.

4. Judith Meurer-Bongardt, Wo Atlantis am Horizont leuchtet oder eine Reise zum Mittelpunkt des Menschen. Utopisches Denken in den Schriften Hagar Olssons, Åbo: Åbo Akademis förlag 20II, s. I3.

5. Roger Holmström, Hagar Olsson och den öppna horisonten. Liv och diktning 1920-I945, Helsingfors: Schildts I993, s. 25; Roger Holmström, "Tiga eller tala? Om Hagar Olssons författarroll under fyrtiotalet”, András Masát (ed.), Literature as Resistance and Counter-Culture. Papers of the Igth Study Conference of the International Association for Scandinavian Studies, Budapest: Hungarian Association for Scandinavian Studies I993, s. I51.

6. Holmström, Hagar Olsson och den öppna horisonten, s. 37, 8I. 
sammanhang efter första världskriget). ${ }^{7}$ Här vill jag undersöka den nämnda förskjutningen mer djupgående och problematisera Olssons syn på modernismen. Jag menar att det förelåg en potentiell spänning mellan försöket att introducera modernistisk avantgardelitteratur och försvaret av den kollektivt engagerade författartyp hon föredrog. ${ }^{8}$ Det tycks inte ha varit självklart att de roller Olsson i praktiken spelade och de ideal hon förespråkade alltid gick att kombinera. ${ }^{9}$ Samtidigt som hon sökte introducera modernismen kom hennes journalistiska karriär att i viss mån exkludera henne från tidens riktiga avantgarde. Därmed intog hon snarare rollen som en massamhällets engagerade tolk i förhållande till modernismen. ${ }^{10}$

7. Jfr t.ex. Roger Holmström, "Modernisternas prosa", utg. Clas Zilliacus, Finlands svenska litteraturbistoria. Andra delen: Igoo-talet, Helsingfors: SLS 2000, s. I04 och Holmström, Hagar Olsson och den öppna horisonten, s. I45. Se även Michel Ekman, "Modernisterna i kritik och debatt", utg. Clas Zilliacus, Finlands svenska litteraturhistoria. Andra delen: I9oo-talet, Helsingfors: SLS 2000, s. II5-I22, Torsten Pettersson, Gåtans namn. Tankens och känslans mönster hos nio finlandssvenska modernister, Skrifter utgivna av Svenska litteratursällskapet i Finland (SSLS) 629, Helsingfors: SLS 200I, s. 9-18 och Helen Svensson, "Hagar Olsson och 30-talets idévärld", Sveinn Skorri Höskuldsson (ed.), Ideas and Ideologies in Scandinavian Literature since the First World War. Proceedings of the Ioth Study Conference of the International Association for Scandinavian Studies, held in Reykjavik, July 22-27, 1974, Reykjavík: University of Iceland, Institute of Literary Research I975, s. 3 or.

8. Jag har i ett annat sammanhang undersökt hur en spänning mellan esteticism och engagemang aktualiserades i svenska litteraturdebatter som bl.a. Hagar Olsson deltog i under I940-talet. Se Hampus Östh Gustafsson, "Dikten i'den nya fredens värld'. Litteraturdebatt i tidskriften Samtid och Framtid I944-I949", Samlaren I37, 20I6, s. I8I-206. För en kritisk diskussion av spänningen mellan l'art pour l'art och engagemang i relation till Jean-Paul Sartres lansering av la littérature engagée genom essän "Qu'est-ce que la littérature?" (1948), se Theodor W. Adorno, "Engagement" [1962] i Gesammelte Schriften. Bd. II. Noten zur Literatur, Frankfurt am Main: Suhrkamp 1974, s. 409-430.

9. Jfr Ellen Rees, On the Margins. Nordic Women Modernists of the I93os, Norwich: Norvik Press 2005, s. I38-I43, som menar att tvetydighet överlag är ett grundläggande element i modernistisk litteratur som skrevs av kvinnor i Skandinavien under r930-talet.

Io. Som Svanberg noterat krävde Olsson engagemang av såväl författarna som litteraturkritikerna. Se Svanberg, "Med ansvar för hela mänskligheten”, s. 227. Ett standardverk om förhållandet mellan den litterära samhällseliten och den moderna tidens nya masskultur är John Carey, The Intellectuals and the Masses. Pride and Prejudice among the Literary Intelligentsia, I880-I939, London: Faber 1992. Begreppet "massor" användes som vi ska se av Olsson själv och jag anknyter här till det för att ta fasta på hennes egen erfarenhet av samhällets förändringar under I 900 -talet och återkommande ställningstaganden för litteratur som gjordes angelägen för ett större samhälleligt kollektiv. 
Syftet med den här artikeln är att undersöka Hagar Olssons syn på författarskap och hennes förhållande till modernismen från I920till r940-talet (hennes mest produktiva period) och hur den tog sig uttryck i hennes egen essäistik. Jag uppmärksammar därmed centrala mekanismer i den författarskapets omprövningsprocess Holmström nämner, för att ge en fördjupad förståelse för hur författarroller kan omförhandlas i tider av kris och krig. ${ }^{11}$ Olssons skrifter relateras här till samhällsutvecklingen i stort, framför allt till hur hon reagerade på världskrigen och det mörkare omvärldsläget under mellankrigstiden. Hennes texter betraktas som aktiva inlägg i en offentlig kulturdebatt där den modernistiska författarens samhällsroll inte var given utan föremål för en pågående omförhandling. ${ }^{12}$ Judith Meurer-Bongardt har i sin avhandling Wo Atlantis am Horizont leuchtet (2OII) undersökt det utopiska i Hagar Olssons författarskap. Hon visar övertygande hur Olsson, influerad av Ernst Bloch, menade att litteratur och konst borde fungera som handling med utopisk potential genom att expressionistiskt gestalta en föraning om en kommande realitet. ${ }^{13}$ I enlighet

II. För förhållandet mellan litteratur och politik under perioden, se Johan Wrede, "Om politiska ideologier och litteratur i Finland I917-I948" i Sven Linnér (red.), Från dagdrivare till feminister. Studier i finlandssvensk 19oo-talslitteratur, Skrifter utgivna av Svenska litteratursällskapet i Finland (SSLS) 537, Helsingfors: SLS I986, s. 169-I94.

I2. I enlighet med Meurer-Bongardts tolkning bör det beaktas att Olsson även i sina kritiska essäer medvetet rörde sig i en litterär eller konstnärlig diskurs som följde andra regler än den mer utpräglat samhällspolitiska. Se Meurer-Bongardt, Wo Atlantis am Horizont leuchtet, s. 74 f., I88 f., I98. Olsson beskrev t.ex. själv litteraturkritiken just som en konstnärlig genre. Se Hagar Olsson, "Om konsten att kritisera", Hagar Olsson, Tidiga fanfarer och annan dagskritik, Stockholm: Natur och Kultur I953, s. II7-I24.

I3. Meurer-Bongardt, Wo Atlantis am Horizont leuchtet, s. I24 f. Jfr Judith Meurer, "Mellan undergång och uppbrott. Apokalypsen som tankefigur i Hagar Olssons författarskap under mellankrigstiden", Michel Ekman \& Kristina Malmio (red.), Bloch, butch, Bertel - Kontextuella litteraturstudier, Helsingfors/Åbo: Avd. för nordisk litteratur, NORDICA, Helsingfors universitet/Litteraturvetenskap, Åbo Akademi 2009, s. I22-I24 och Judith Meurer-Bongardt,"Varför Hagar Olsson? Varför Utopi?", Finsk tidskrift 2013:5, s. 55-64. Om Olssons förhållande till den internationella expressionismen, se Roger Holmström,"'Det självverksamma ögat'. Hagar Olsson och tysk expressionism i början av I920-talet", Finsk tidskrift I993:I, s. I-II. För en intressant studie av den expressionistiska prosans roll i det tidiga I9oo-talets omförhandling av konstens mål och medel, där Olsson behandlas återkommande, se Gunilla Hermansson, Modernisternas prosa och expressionismen. Studier i nordisk modernism 19I0-I930, Göteborg: Makadam 2015. 
med denna uppfattning vill jag uppmärksamma vad Olsson försökte göra genom sina essäer, särskilt på vilket sätt hon tog ställning för engagerad litteratur framför l'art pour l'art genom att slutligen mobilisera sig själv litterärt som ett aktivt författarjag.

Jag använder här begreppen engagerad litteratur och l'art pour l'art som två idealtypiska poler för att fixera Olssons litteratursyn vid olika tillfällen. L'art pour l'art hade vanligen individualistiska konnotationer, medan engagerad litteratur tog fasta på litteraturens ansvar inför samhället i bredare bemärkelse och i mer kollektiv mening. För Olsson syntes det senare angeläget då hon, $\mathrm{i}$ likhet med många samtida, utgick från att 1900-talet hade inneburit framväxten av en ny masskultur. L'art pour l'art hade under I8oo-talet (företrädesvis inom en fransk tradition) anammats av aktörer på det litterära fältet som ett medel för att legitimera avantgardistisk konst och litteratur genom att värdesätta konstens självändamål framför dess politiska eller moraliska betydelse. ${ }^{14}$ Att Olsson förkastade l'art pour l'art till förmån för en mer socialt engagerad hållning är redan väl belagt, men att undersöka hur hon gjorde det och varför det framstod som så viktigt för henne vid olika tidpunkter är en angelägen forskningsuppgift som ger en djupare inblick i vad som stod på spel i den litterära debatten under tiden från första till andra världskriget.

I min undersökning noterar jag också Olssons kraftfulla (och ofta bibliskt inspirerade) bildspråk. En analys av den diskursiva funktionen hos de troper Olsson använde i samband med att hon skrev om författarskap och modernism ger en möjlighet att resonera kring hur hennes idéer kan förstås i en större historisk kontext och hur Olsson positionerade sig själv som författare. ${ }^{15}$ Hennes val av metaforer im-

I4. Pierre Bourdieu, Konstens regler. Det litterära fältets uppkomst och struktur, övers. Johan Stierna, Stockholm/Stehag: Brutus Östlings Bokförlag Symposion 2000 [1992], s. 92, 3I7 f., $475 \mathrm{f}$.

15. Bo Lindberg har t.ex. påpekat att just metaforer "är tacksamma som studieobjekt eftersom de antingen är expressiva förtätningar av vad författaren vill säga eller också - och intressantare - låter ana förutsättningar för tänkandet varom författaren själv inte är medveten”. Se Bo Lindberg,"Retorik och idéhistoria”, Kurt Johannesson (red.), Vetenskap och retorik. En gammal konst i modern belysning, Stockholm: Natur och Kultur 200I, s. I77. Anna Möller-Sibelius har även uppmärksammat hur just bildspråket hos Bertel Gripenberg respektive Hagar Olsson blottar "en pågående kamp om tolkningsföreträde och litterär syn", samt en "generationsmotsättning" mellan dessa två, inte minst i efterspelet till Gripenbergs publicering av Den hemliga 
plicerar i flera fall specifika historietolkningar och förväntningar på framtiden, och metaforerna ingår som byggstenar i historiska berättelser som användes i en diskursiv kamp om att definiera samhällets framtida utveckling. Berättelsernas karaktär implicerade specifika roller för författaren och modernismen, vilket är särskilt intressant att uppmärksamma med tanke på modernismens upptagenhet av framtiden. ${ }^{16}$ Min analys är dock avgränsad till Olssons egna texter, snarare än att undersöka de vidare debatter hon deltog i.

År 1925 publicerade Olsson essäsamlingen $N y$ generation, år 1935 Arbetare $i$ natten och år $1948 \mathrm{Jag}$ lever. Till stora delar innehåller dessa författarporträtt, men också mer allmänt hållna programtexter som diskuterar modernismens och författarnas roller i samtidskulturen. Exempel på sistnämnda i respektive volym är "Dikten och illusionen" (I925), "Mörka vägar" (I935) och "Författarskapets dekadens” (I948). ${ }^{17}$ Essäerna är av jämförbart omfång, har liknande innehåll och ger tre tidsmässigt åtskilda nedslag som utgör lämpliga utgångspunkter för att närma sig frågorna ovan. ${ }^{18}$ Just Olssons essäer har tilldragit sig

glöden (I925) under det påhittade namnet Åke Erikson (i ett försök att förlöjliga den modernistiska poesin), som reflekterade en allmän motsättning mellan traditionalister och modernister i svensk och finlandssvensk debatt under 1920-talet. Se Anna Möller-Sibelius, Roll, retorik och modernitet i Bertel Gripenbergs lyrik, Skrifter utgivna av Svenska litteratursällskapet i Finland (SSLS) 791, Helsingfors: SLS 2015, s. 22I-262, men även Holmström, Hagar Olsson och den öppna horisonten, s. I2O-I22.

I6. Jfr t.ex. Svensson, "Hagar Olsson och 30-talets idévärld", s. 309, som har uppmärksammat hur Olsson under I930-talet skrev in modernismen i ett "tidsdrama".

I7. Huvuddragen i "Dikten och illusionen" presenterades först i föredraget "Dikt och utopi" i Lund 2I/9 I925 för att senare tryckas i den socialistiskt inriktade tidskriften Clarté (utgiven sedan 1924). Se Holmström, Hagar Olsson och den öppna horisonten, s. 96. "Författarskapets dekadens" publicerades ursprungligen i den svenska tidskriften Samtid och Framtid 1944 med en något annorlunda titel. Se Hagar Olsson, "Om författarskapets dekadans", Samtid och Framtid I944:2, s. 5-15.

I8. Andra texter hade också kunnat inkluderas i undersökningen, inte minst titelessän från I948, ”Jag lever"'. Den är dock betydligt längre och fokuserar mer på allmänna livsåskådningsfrågor än litteratur och författarskap. Meurer-Bongardt och Maria Wegelius har dessutom redan behandlat den utförligt. Holmström har även diskuterat "Författarskapets dekadens", men i en ganska kortfattad artikel. Se Meurer-Bongardt, Wo Atlantis am Horizont leuchtet, s. 435-458, Maria Wegelius, Civilisation kontra inre människa. En studie i 'Jag lever' med utgångspunkt i Hagar Olssons 40-tal, Meddelanden nr I6, Åbo: Åbo Akademi, Litteraturvetenskapliga institutionen I99I och Holmström, "Tiga eller tala?", s. I5I-I56, men även Hampus Östh Gustafsson, "Dikt och demokrati. Hagar Olssons stridsrop i andra världskrigets skugga", Horisont 2015:I, s. 39-4I. 
allt större intresse $\mathrm{i}$ forskningen, inte minst som de speglar viktiga drag i hennes skönlitterära produktion. ${ }^{19}$

Vad gäller essäformen är det viktigt att tänka på dess flexibilitet. Av Magnus von Platen har den lyfts fram som en litteraturart med påtagligt mjuka gränser och som därför kan tas i många olika riktningar. $^{20}$ Traditionellt sett har jaget i essän uppfattats som en biografisk representation av författaren, men som Emma Eldelin understrukit handlar det ofta mer" om ett språkligt konstruerat jag och en offentlig författarroll”. ${ }^{21} \mathrm{I}$ anslutning till frågan om Hagar Olssons syn på författarskap är det därför även intressant att se hur hon konstruerar sig själv som jag och författare i essäerna som här står i fokus. ${ }^{22}$ Som Graham Good föreslagit kan essän betraktas som en personlig vittnesakt. Essän är enligt honom på samma gång inskrivandet av ett jag och beskrivningen av ett objekt. ${ }^{23}$ I enlighet med detta synsätt vill jag

I9. Se Meurer-Bongardt, Wo Atlantis am Horizont leuchtet, s. 343, men även Madeleine Person, I ideologiernas och Guds skugga. Hagar Olssons litteraturkritik och essäistik i ett idébistoriskt perspektiv, Masteruppsats, Lund: Litteratur-Kultur-Medier, Lunds universitet 20I4, http://lup.lub.lu.se/student-papers/record/429436o (hämtad II/9 2018).

20. Magnus von Platen, Skandalen på Operakällaren och andra essayer, Stockholm: Fischer \& Co. 1996, s. III. För ytterligare diskussioner av essägenrens särart, se Anders Westerlund,"Essäistik mellan vetenskap och konst. Paratextuella signaler i Hans Ruins Gycklare och apostlar", Historiska och litteraturhistoriska studier 9I, Helsingfors: Svenska litteratursällskapet i Finland (SLS) 20I6, s. 98, I24 och Göran Hägg, Övertalning och underhållning. Den svenska essäistiken I890-I930, Stockholm: Wahlström \& Widstrand I978, s. I4. För en analys av den finlandssvenska essätraditionen, se Patrik Aaltonen, En genres förvandlingar. Om genrebeteckningen essä och den svenskspråkiga essäistiken i Finland I90o-1920, Avhandling pro gradu, Helsingfors: Finska, finskugriska och nordiska institutionen, Helsingfors universitet 20I3, https://helda.helsinki.fi/bitstream/handle/ror38/40768/engenres.pdf ?sequence $=$ I (hämtad 28/4/20I8).

2I. Emma Eldelin, "Essäisten som generalist. Författarroller och offentlig auktoritet hos tre samtida essäister", Tidskrift för litteraturvetenskap 2009:3-4, s. 82. Se även Emma Eldelin, Att slå dank med virtuositet. Reträtten, sysslolösheten och essän, Lund: Ellerströms 20I8, fr.a. kap. I-2. Jfr med kritiken mot biografisk-psykologiska tolkningar av Olssons författarskap i Meurer-Bongardt, Wo Atlantis am Horizont leuchtet, s. $192 \mathrm{f}$.

22. Hur Olsson konstruerar berättarjag i sin romankonst har t.ex. diskuterats av Katarina Leppänen \& Therese Svensson, ”Om naturupplevelser hos Elin Wägner och Hagar Olsson. Lästa i eko- och vithetskritisk belysning", Tidskrift för genusvetenskap 37:I, 20I6, s. II-3I.

23. Graham Good, The Observing Self. Rediscovering the Essay, London \& New York: Routledge I988, s. 23. 
undersöka hur Olsson skriver in sig själv i sina essäer och hur det sker i samspel med de olika historiska situationer hon reflekterar över.

De tre essäerna analyseras här i kronologisk ordning med Olssons syn på författarskap och modernism i fokus. Vad som skiljer min undersökning från den tidigare forskningen, som har belyst essäerna och deras respektive teman, är att jag utför en mer samlad komparation av dem för att fördjupa förståelsen av Olssons litterära positionering och syn på författarskap och modernism över tid.

\section{ETT HISTORISKT BROTT OCH MODERNISMEN SOM FRAMTIDSRÖRELSE}

Ny generation har beskrivits som "Hagar Olssons genombrottsbok som kritiker, där hon lanserade 'framtidens diktning"'. ${ }^{24}$ Omedelbart i den inledande essän "Dikten och illusionen" vänder sig Olsson mot vad hon betraktar som en äldre typ av författare (med förankring $\mathrm{i}$ I89o-talet) som hade fokuserat på individuella värden och därmed isolerat sig själva från samhället. Till sist hade deras litteratur kommit att utarmas: "Den var isolerad, och betydelselös: en kvarleva av något som en gång varit, en skugga av sig själv". ${ }^{25} \mathrm{I}$ det här tidiga skedet formulerar Olsson sitt litterära ideal och positionerar sig i kontrast till det aristokratiska och individualistiska, men också till nationellt inriktade författare. Hon använder inte själv den klassiska elfenbenstorn-metaforen för att karaktärisera deras isolering, utan talar i stället om att den äldre författartypens litteratur stängt "in sig i en konstgjord stad med noli me tangere-murar på alla håll". ${ }^{26}$ Men enligt Olsson blir den äldre författartypen överspelad i det samtida

24. Svanberg,"Med ansvar för hela mänskligheten”, s. 227. Lägg märke till hur boktiteln sedan kom att återspeglas i undertiteln för tidskriften Quosego, som löd: Tidskrift för ny generation. Jfr Zilliacus, "Världsherraväldets lokalvisor", s. xx.

25. Hagar Olsson, "Dikten och illusionen", Hagar Olsson, Ny generation, Helsingfors: Schildts I925, s. 7 .

26. Olsson, "Dikten och illusionen", s. 8. Det latinska uttrycket betyder "rör inte vid mig". Enligt Johannesevangeliet yttrades orden av Jesus till Maria Magdalena efter uppståndelsen. Se Joh 20:I7. För en diskussion av begreppet "elfenbenstorn", se Steven Shapin, "The Ivory Tower. The History of a Figure of Speech and Its Cultural Uses", The British Journal for the History of Science, 45:I 2012, s. I-27, https:// doi.org/ıo.IoI7/Sooo70874I2000II8 (hämtad Io/5/2018). 
brytningsskedet. Ellen Rees har uppmärksammat detta som ett av de mest karaktäristiska dragen hos den unga Hagar Olsson, att hon bar på en övertygelse om att hon levde under en stark litterär förändringsperiod och därmed ständigt sökte efter det nya och förkastade vad hon upplevde som gammalt. ${ }^{27}$ Inte helt överraskande pekade Olsson ut första världskriget som det radikala brottet i litteraturhistorien. I "Dikten och illusionen" använde hon händelsen som utgångspunkt för att lansera den modernistiska generationen som reste sig ur krigets aska. Den tecknades av Olsson som en brokig men ändå sammanhållen rörelse som hade "vind i seglen" och färdades i hög fart med siktet inställt på framtiden. De nya skaldernas "sång är dagens sång till morgondagen - den kan inte blicka tillbaka på sjunkna båtar och bleknade döde", proklamerar hon med en syrlig pik till den äldre författartypen. ${ }^{28}$ Hennes syn på modernismens framtida möjligheter är här mycket optimistisk.

Själva krigserfarenheten blev en utmaning för l'art pour l'artidealet. "Vid tiden för världskriget trängde stridsgnyet på nytt fram till poeternas underbara stad, som de förklarat fridlyst till evig tid" - så menar Olsson att kriget påverkade estetiken. ${ }^{29}$ Som Holmström noterat bidrog krigshändelserna till att öppna Olssons ögon för omvärlden. ${ }^{30}$ Det är emellertid inte bara världskriget som utgör en förändringsfaktor på estetikens område. Även mer interna strömningar, som naturalismen, menar hon haft stor betydelse genom att prioritera det kollektiva framför det individuella. Härmed påtalas också en brytning

27. Rees, On the Margins, s. I22.

28. Olsson, "Dikten och illusionen", s. II, I3.

29. Ibid., s. 9 f. För andra intressanta exempel på hur första världskriget påverkade litteraturen, men ur ett svenskt perspektiv, se Claes Ahlund, "En mental militarisering. Den svenska litteraturen före och under första världskriget", Samlaren $\mathrm{I} 24,2003$, s. I34-157 och Claes Ahlund, Diktare i krig. K. G. Ossiannilsson, Bertil Malmberg och Ture Nerman från debuten till I920, Skrifter utgivna av Avdelningen för litteratursociologi vid Litteraturvetenskapliga institutionen i Uppsala 55, Hedemora: Gidlunds förlag 2007.

30. Holmström, Hagar Olsson och den öppna horisonten, s. 22. Det är också viktigt att komma ihåg att Olsson starkt påverkades av det finska inbördeskriget. Se MeurerBongardt, Wo Atlantis am Horizont leuchtet, s. Io6, och för en allmän redogörelse för inbördeskrigets inverkan på litteraturen, se Johan Wrede, "Inbördeskriget i litteraturen", utg. Clas Zilliacus, Finlands svenska litteraturhistoria. Andra delen: Igoo-talet, Helsingfors: SLS 2000, s. 6I-67. 
mellan de gamla individualisternas desillusion och de "illusioner" som hon menar bär fram den nya litteraturen som är präglad av"ett socialt medvetande och en gemensam kollektivdröm, en utopi". ${ }^{31}$ Första världskriget blev enligt Olsson den avgörande erfarenheten som ledde till att europeisk litteratur skulle omfamna illusionerna på allvar och anamma den kollektivistiska utopin. ${ }^{32}$ Erfarenheten gav incitament att sträva efter en mer aktiv litteratur med handlingspotential. ${ }^{33}$

Som Lars Gustafsson beskrivit blev frågan om den västerländska kulturens öde (i Oswald Spenglers efterföljd) ett centralt motiv i mellankrigstidens litteratur och ideologiska debatt. Denna fråga kunde besvaras antingen pessimistiskt, med fokus på ett övergivande av traditionen och äldre livsformers upplösning, eller optimistiskt, så att den traditionella kulturens undergång sågs som en förutsättning för framväxten av en ny och mer vital sådan, en tanke som inte sällan beledsagades av socialistiskt inspirerade idéer. ${ }^{34}$ Det mer optimistiska tolkningsalternativet var inte Olsson främmande i "Dikten och illusionen". Över huvud taget kom hon under I920-talets mitt, särskilt efter en vistelse i Estland, att visa ett större intresse för litteratur som hon menade hade en reell möjlighet att leda till social eller politisk

3r. Olsson,"Dikten och illusionen", s. 9.

32. Jfr Meurer-Bongardt, Wo Atlantis am Horizont leuchtet, särskilt s. I88-224. Det utopiska i Olssons tidiga författarskap behandlas även av Pertti Karkama, "Die Geburt der Utopie in der frühen Prosa Hagar Olssons", George C. Schoolfield \& Laurie Thompson (eds.), Two Women Writers from Finland. Edith Södergran (1892-1923) and Hagar Olsson (1893-1978), Edinburgh: Lockharton Press I995, S. $183-197$.

33. I en jämförelse mellan Hans Ruin och Hagar Olsson har Thomas Ek menat att Olsson hade en mer upprorisk syn på den modernistiska litteraturens funktion. Se Thomas Ek, "Hans Ruin och den finlandssvenska modernismen", Tidskrift för litteraturvetenskap, 30:2 200I, s. 64-70.

34. Lars Gustafsson,"Den västerländska kulturens stympade lemmar - Idéer om kulturens undergång och kulturens förnyelse i svensk litteratur efter första världskriget", Sveinn Skorri Höskuldsson (ed.), Ideas and Ideologies in Scandinavian Literature since the First World War. Proceedings of the Ioth Study Conference of the International Association for Scandinavian Studies, held in Reykjavik, July 22-27, I974, Reykjavík: University of Iceland, Institute of Literary Research $1975, \mathrm{~s}$. $72 \mathrm{f}$. Det bör nämnas att Olsson tidigt under 1920-talet inspirerades av Clarté-rörelsen (vilken hon försökte etablera i Finland) som uttryckte stora visioner om författarnas ansvar och möjligheter att påverka och skapa en ny, bättre värld. Se Helen Svensson, "Clarté i Finland", Historiska och litteraturbistoriska studier 54, Helsingfors: Svenska litteratursällskapet i Finland (SLS) 1979, s. I60 f. 
förändring. ${ }^{35} \mathrm{Vi}$ ska dock komma ihåg att Olssons litterära vägval, så som exempelvis Johan Wrede poängterat, blev utopism i stället för en hårdare sociopolitisk realism. ${ }^{36}$

Den ideala modernistiska författaren tecknas av Olsson som kollektivistiskt lagd och inriktad på en "profan demokratisk miljö". Likaså har hen inspirerats av naturalismen och realismen, men tagit dessa genrer vidare till en nivå som Olsson kallar "nyrealism" och som har den utopiska potential Meurer-Bongardt belyst ingående. ${ }^{37}$ Olsson talar om "en utopi som kräver strid, en skönhet som måste tillkämpas - ofta fjärran från de estetiska slagfälten!”. ${ }^{38}$ Författaren ska alltså kasta bort de estetiska skygglapparna. Också Maria Wegelius har konstaterat att Olsson i flera sammanhang tog "avstånd från en estetiserande l'art pour l'art" till förmån för "en stark tro på en konstens stora mission, en l'art pour l'homme". Hon menar att Olsson 1925 talade "för en socialt och etiskt engagerad litteratur, där föreställningen om en ny kollektiv livskänsla är central." ${ }^{39}$ Den kanske tydligaste sammanfattningen av sitt författarideal ger Olsson själv när hon skriver att den nya skalden står "mitt uppe i dagen, med ansiktet vänt mot det brusande människohavet". ${ }^{40} \mathrm{Med}$ noli me tangere-murarna rivna efter kriget tycks Olsson se det som ganska oproblematiskt för de författare som känner sig manade att ta steget ut och författa litteratur som på allvar betyder något för det

35. Lena Fridell, Hagar Olsson och den nya teatern. Teatersynen speglad i teaterkritiken I9I8-I929 och $i$ Hjärtats pantomim, Göteborg: Litteraturvetenskapliga institutionen, Göteborgs universitet 1973, s. I7-22; Holmström, Hagar Olsson och den öppna horisonten, s. 84-9o.

36. Johan Wrede, "Illusion - utopi - realism. Edith Södergran, Hagar Olsson och Finland omkring I920", Finsk tidskrift, I974:3, s. 28I.

37. Meurer-Bongardt, Wo Atlantis am Horizont leuchtet, s. 96-105.

38. Olsson, "Dikten och illusionen", s. I3-16.

39. Wegelius, Civilisation kontra inre människa, s. 93 f. Se även Svensson,"Hagar Olsson och 30-talets idévärld", s. 3or. Ny generation kom också att uppfattas som ett uttryck för socialistisk propaganda, även om Olsson själv värjde sig mot en sådan etikettering. Se Holmström, Hagar Olsson och den öppna horisonten, s. 99. Olsson ville ständigt hålla konsten och litteraturen oavhängiga av det partipolitiska. Se Meurer-Bongardt, Wo Atlantis am Horizont leuchtet, s. 199-201, 2 Io.

40. Olsson,"Dikten och illusionen", s. Ir. Holmström har vidare understrukit att Olssons litteraturuppfattning vid mitten av I920-talet bl.a. utmärktes "av ett avståndstagande från varje form av estetiskt poserande". Se Holmström, Hagar Olsson och den öppna horisonten, s. IO2. 
stora flertalet. Hon verkar inte se några egentliga hinder längs den engagerade författarens väg till det mänskliga kollektivet.

Synen på den historiska utvecklingen som uttrycks i "Dikten och illusionen" ter sig närmast deterministisk. Hagar Olsson verkar fullständigt övertygad om att den isolerade författartypen håller på att bytas ut mot den nya, modernistiska och socialt engagerade författaren. Första världskriget, i egenskap av ett absolut historiskt brott, framställs då som en språngbräda för den nya författartypen som kunde ta över ledningen och lämna äldre estetiska ideal bakom sig $\mathrm{i}$ skyttegraven. Genom denna historiska berättelse, där krigserfarenheten betecknar en estetisk emancipation, skapas spelutrymme för modernisterna, de som bär framtiden i sitt sköte. I essän skriver hon dock inte fram något urskiljbart jag. ${ }^{41}$ I stället tycks hon ta på sig rollen att ur en tillbakahållen position beskriva den förändring hon menar att samtiden står mitt uppe i. Men var det rimligt att upprätthålla ett så neutralt författarjag när nya, hårdare vindar började blåsa under I930-talet? Och kunde modernismen då undgå att blicka bakåt när framtidshorisonten mörknade?

\section{Modernismen Som AVANTgarde i etT DIALEKTISKT SPEL}

Redan den första meningen i "Mörka vägar" anslår en kontrast gentemot"Dikten och illusionen" vad gäller synen på den kulturhistoriska utvecklingen. I930-talets nya tidsskeende"driver [O1sson] till en revision av 20-talets framtidsutopier och till en nytolkning av modernismen”, enligt Helen Svenssons sammanfattning. ${ }^{42}$ Den enkelriktade, utopiska resan mot en ljus framtid har delvis ställts in. "Kulturens liksom den enskildes utveckling synes fortgå i cykler som upphäver varandra och ändå fortbestår i varandra, liksom dag och natt i det

4I. Som ung kritiker förespråkade Olsson personlig framtoning men vände sig samtidigt mot självupptagenhet hos författare, t.ex. i en anmälan av Rolf Lagerborgs Invita Minerva (I9I8). Se Holmström, Karakteristik och värdering, s. I79 f.

42. Svensson,"Hagar Olsson och 30-talets idévärld", s.309. Om Olsson i relation till de allmänt förändrade kulturella stämningarna i Finland från I930-talet, se Johannes Salminen, "Vägen till Weimar. Kulturklimatet i Finland på r930- och r940-talet", Nya Argus, 80:6-7 1987, s. I16-I20 och Gisbert Jänicke,"Hagar Olsson mellan natt och dag", Nya Argus, 80:6-7 I987, s. I2I-I26. 
kosmiska förloppet”, inleder Hagar Olsson essän. ${ }^{43}$ Modernismen antas inte längre ha uppstått som ett plötsligt singulärt fenomen på I90o-talet: "Modernismen är ingalunda något som vår tid uppfunnit - dess vågrörelse går genom alla tiders litteratur". ${ }^{44}$ Till exempel lyfter hon inom citationstecken fram Rousseau som en tidigare "modernist" i etableringsskedet av det hon kallar för "den borgerliga revolutionsepoken" ${ }^{45}$ Föreställningen om hennes egen samtid som ett unikt historiskt brott tonas ned, även om brytningsmotivet finns kvar. $\mathrm{Nu}$ tecknas hennes samtid som en mer komplex period.

Ska man definiera en historiesyn hos Olsson så är den i "Mörka vägar" dialektisk. ${ }^{46}$ Hon menar att samtiden kommit att präglas av inre motsättningar. Modernismen vittnar om detta, om "spänningen mellan det förfutna och det kommande, tillspetsad och aktualiserad $i$ det beståendes kris" ${ }^{47}$ Genom historien hävdar hon att ljusa, harmoniska perioder omväxlande har avlösts av just brytningstider präglade av mörker, pessimism och krig. Som Meurer-Bongardt påpekat är Olsson här inspirerad av den bibliska apokalyptiska tankefigur som under mellankrigstiden var inflytelserik såväl i politiska som konstnärliga diskurser. Den spelade allmänt en viktig roll inom modernismen; undergången möjliggjorde nytt liv. ${ }^{48} \mathrm{På}$ I920-talet tycktes Olsson förknippa modernismens inbrytning med en utopiskt upplyst framtidshorisont - nu anpassar hon i stället modernismen och menar att det är i mörka tider litteraturen är mest meningsfull.”Då är diktarens uppgift en förposttjänst - hård, oskön men av grundläggande betydelse för morgondagen". ${ }^{49}$

43. Hagar Olsson, "Mörka vägar”, Hagar Olsson, Arbetare i natten, Stockholm: Natur och Kultur 1935, s. 9. Olsson uppvisar här en tydlig inspiration från Spengler. Se Svensson, "Hagar Olsson och 30-talets idévärld", s. 3ro.

44. Olsson, "Mörka vägar", s. I8.

45. Ibid., s. 24 .

46. Jfr Meurer-Bongardt, Wo Atlantis am Horizont leuchtet, s. Io6-1o9 och Svensson, "Hagar Olsson och 30-talets idévärld", s. 3ro. Vissa tecken på en dialektisk uppfattning framträder redan i "Dikten och illusionen", särskilt genom ett citat av Elmer Diktonius. Se Olsson, "Dikten och illusionen”, s. I5 och jfr Meurer-Bongardt, Wo Atlantis am Horizont leuchtet, s. I05.

47. Olsson, "Mörka vägar", s. I8.

48. Meurer,"Mellan undergång och uppbrott", s. I2I, I25; Meurer-Bongardt, Wo Atlantis am Horizont leuchtet, s. I08-IIo.

49. Olsson, "Mörka vägar", s. I3. 
Holmström har dock menat att Olsson distanserade sig en aning från modernismen under tidigt 1930-tal. Hennes strävan gick nu ut på att mobilisera författaren och modernismen "mot tidens tilltagande reaktionära tyranni" i ett försök att frambesvärja "en diktartyp som svarar mot tidens utmaningar". ${ }^{50}$ Det är därför Olsson omvandlar modernisten till en arbetare i natten som använder de mörka stämningarna på ett förlösande vis "i hungermarschernas, koncentrationslägrens och det förfärande krigsspökets tid, i en värld full av själslig och materiell nöd" ${ }^{51}$ Rörelsen tecknas dock fortfarande som omöjlig att stoppa. Trots att den förlöjligats i vissa kretsar pekar Olsson alltjämt ut modernismen som en vägvisare mot framtiden. ${ }^{52}$

Värt att notera är att Olsson lägger stor vikt vid yttre, snarare än inre, personliga drivkrafter för den historiska utvecklingen.”Så stark är verklighetens makt", skriver hon bland annat, och menar att modernismen kommer att gå segrande fram tack vare sin verklighetsanknytning. ${ }^{53}$ Som en socialistiskt inspirerad rörelse kan modernismen vara avantgarde, men det är alltså en särskild typ av avantgardelitteratur hon förespråkar. Den ska vara verklighetsförankrad samt kollektivt och socialt engagerad. Det är just genom att inte vara l'art pour l'art som den modernistiska litteraturen blir avantgarde. Enligt hennes dialektiska synsätt måste samtidens antitetiska krafter dock spelas ut mot varandra innan framtidens syntes kan födas, men hon är övertygad om att modernismen ska bidra till sökandet efter"en ny och djupare nående syntes" ${ }^{54}$ Först måste det gamla dö: "Natten måste djupna innan morgondagen gryr" ${ }^{55}$ Bilden av modernismen som avlösare av

50. Holmström, Hagar Olsson och den öppna horisonten, s. I6I, 257.

51. Olsson, "Mörka vägar", s. 37 .

52. Ibid., s. I2-I4, 22. Olsson riktar särskilt kritik mot Fredrik Böök och det hon kallar för "auktoritativ" litteraturkritik som hon menar inte hade förstått sig på modernismen.

53. Ibid., s. $3^{8}$.

54. Ibid., s. 19, 23 .

55. Ibid., s. II. "Mörka vägar" föregås av ett citat av Stagnelius dikt "Vän! i förödelsens stund" (ca I8r8) som sätter tonen för hela essäsamlingen med den berömda slutraden "Natten är dagens mor, Kaos är granne med Gud", vilket indikerar hur Olsson såg mörkret som en källa till kreativitet och nödvändig förnyelse. Se Erik Johan Stagnelius, Samlade skrifter. Andra delen. Lyriska dikter efter tiden omkring I8I8. Liljor i Saron, Fredrik Böök (red.), Stockholm: Bonniers I9I3, s. 54. Olsson var tydligt influerad av romantikens litteratur, inte minst vad gäller förvissningen om 
en traditionell litteratur tecknas här mer komplext än i "Dikten och illusionen". Modernismen är ännu framtidens vägvisare, men dess författare måste ha tålamod och vänta ut ett dialektiskt spel.

Den tes modernismen vänder sig mot beskriver Olsson i "Mörka vägar" som en borgerligt grundad kulturidealism som växte fram under sent I700-tal men nu har tvingats på defensiven. ${ }^{56} \mathrm{I}$ hennes modernism kan vi därmed se en kritik av vissa centrala inslag i moderniteten. Meurer-Bongardt har uppmärksammat att Olsson i "Mörka vägar" kritiserar "synen på människan och verkligheten som 'den tekniskt högutrustade kapitalismens dödsrike, sinnebilden för människans värdelöshet"'. ${ }^{57}$ Modernismen tycks erbjuda ett alternativ till detta. Olsson betonar därmed att "modernismens kulturhistoriska uppgift" är "att bryta med det bestående". ${ }^{58}$ Under I930-talet kom Olsson att inta en mer kulturradikal hållning än tidigare. ${ }^{59}$ Hennes litterära program fortsätter att vara offensivt inriktat då hon väntar sig att modernismen ska åstadkomma förändring.

Trots Olssons påtagliga engagemang framträder inte heller i "Mörka vägar" något särskilt konkret författarjag. Men essän har ändå en något personligare ton än "Dikten och illusionen". Olsson skriver tydligt in sig i ett kollektiv: "Vi som lever mitt inne i en sådan epok [en brytningstid] känner blott alltför väl till dess karakteristika; vi har in i märg och ben fått känna slagkraften av dess negativitet”. ${ }^{60}$ Den kroppsligt inriktade metaforen - "in i märg och ben" - vittnar måhända om hur ett förkroppsligat jag börjat närma sig texten i högre utsträckning än tidigare. Holmström har hävdat att Olsson ställde högre krav på modernismen alltsedan mitten av 1920-talet genom att efterfråga en "inre, tillämpad täckning bakom orden". Att som författare gömma sig bakom ett yttre, stilistiskt och modernistiskt skal var

att hon levde i en brytningstid. Se Roger Holmström, "Romantiken som klangbotten i Hagar Olssons tidiga författarskap", Oskar Bandle et al. (eds.), Nordische Romantik, Beiträge zur nordischen Philologie 19, Basel: Helbing \& Lichtenhain I99I, s. 432-435.

56. Olsson, "Mörka vägar", s. I8, 42.

57. Meurer-Bongardt, "Varför Hagar Olsson?", s. 62 f.

58. Olsson, "Mörka vägar", s. I6.

59. Svensson, "Hagar Olsson och 3o-talets idévärld", s. 302.

6o. Olsson, "Mörka vägar”, s. Io. 
inte tillräckligt. ${ }^{61}$ När vi nu förflyttar oss till Hagar Olssons 1940-tal ska vi se en rejäl skärpning av kraven på personligt engagemang.

\section{DESILLUSION OCH SKÄRPTA KRAV PÅ ENGAGEMANG}

Vid en första anblick kan "Författarskapets dekadens" ge intrycket av att Hagar Olsson hållit fast vid sina ideal på ett oförändrat sätt. Så här inleder hon essän:

Benägenheten att uppfatta litteraturen som en helt isolerad - och som det heter 'opolitisk' - företeelse och hänvisa den till ett slags reservat i samhället, där den saknar kontakt med de opinionsbildande krafternas fria spel, har länge stått för mig som ett oroande tecken på dekadens. ${ }^{62}$

Hon menar alltså att detta är en uppfattning hon burit "länge”. Men i nästa mening möter vi plötsligt ett vittnesmål om att något har hänt. Olsson belyser själv detta genom att uppmärksamma hur erfarenheten av andra världskriget fick henne att se saker i nytt ljus. Hon skriver att"som det ofta händer behövdes det en påstötning av en rad samverkande tillfälligheter för att jag en dag skulle se hela saken i blixtbelysning och få en glimt av de djupare sammanhangen”. ${ }^{63}$

Stunden av blixtbelysning förknippas intressant nog med en konkret tid och plats, närmare bestämt "en februaridag år I943 i mitt hem i Helsingfors", där Olsson beskriver hur hon försökte skriva "efter en ansträngande bombnatt". Att skriva var emellertid svårt då hon distraherades av krigshändelserna. I "denna ödesmättade stund" blev hon sittande i lägenheten, ensam så när som på rösterna från radion som vittnade om omvärldsdramatiken. ${ }^{64} \mathrm{Vi}$ kan knappast ta

61. Holmström, Hagar Olsson och den öppna horisonten, s. I46.

62. Hagar Olsson, "Författarskapets dekadens" [1944], Hagar Olsson, Jag lever, Stockholm: Natur och Kultur 1948, s. I45. Det bör noteras att Olsson i den här essän kritiserar inte bara litteraturens isolering, utan parallellt med den också litteraturens kommersialisering.

63. Ibid., s. I45. Som Svanberg understrukit blev andra världskriget "en fruktansvärd utmaning för Hagar Olssons framtidstro". Se Svanberg, "Med ansvar för hela mänskligheten", s. 23I.

64. Olsson, "Författarskapets dekadens", s. I45-I47. 
Olsson på orden när hon skisserar ovanstående i dramatiska ordalag. Inledningsscenen bör främst betraktas som ett retrospektivt försök att gestalta hur Olsson kände inför den förändrade situation andra världskriget inneburit för både henne själv och den modernism hon så länge omhuldat.

Holmström har också funnit scenen värd att uppehålla sig vid. Han menar att Olsson använde februaridagen i Helsingfors 1943 som ett "förtätningstillstånd" för att ställa kollektivet mot elfenbenstornet, även om hon själv inte talar om just "elfenbenstorn" ${ }^{65}$ Problemet var enligt Olsson att hela författarkollektivet nu hade stängt in sig och tagit avstånd från omvärlden. ”Jag fick plötsligt en vision av Europas alla hemlösa emigrerade författare som satt, liksom jag, vid sina radioapparater i världens skilda hörn och väntade, väntade", skriver Olsson. ${ }^{66}$ Hon menar att kulturen har satts "på piedestal" och blivit en kultur "som när som helst kunde bli slagen i spillror just därför att den inte var en integrerande del av människans liv". ${ }^{67}$ Ännu en gång har litteraturen kommit att uppfattas som ett självändamål. Som vi har sett vände sig Olsson mot sådan l'art pour l'art redan på i920-talet, men då verkade hon se det som ett överspelat stadium. Nu upplever hon att hennes egen modernistiska generation blivit lika goda kålsupare. L'art pour l'art och modernismen tycks plötsligt ha flutit samman, efter att Olsson tidigare försökt definiera dem som varandras fiender. Föga överraskande sporras hon av detta till en djup självrannsakan, både av sitt eget författarskap och hela det modernistiska projektet. ${ }^{68}$

65. Holmström, "Tiga eller tala?", s. I52. I ett annat manuskript till essän går det, som Holmström lagt märke till, att se hur Olsson laborerade med en inledning där hon även ställde nuet i relation till röster från första världskriget och I920-talet. Hon tycks ha lagt ned åtskillig möda på att utarbeta just den här inledningen.

Filosofen Rolf Lagerborg tog fasta på Olssons text som ett inlägg i "de gamla grälen om 'elfenbenstornet' och om l'art pour l'art'. Essän, som ursprungligen var ett inlägg i tidskriften Samtid och Framtid, väckte en hel del debatt. Se Rolf Lagerborg, "Diktaren och propagandan", Samtid och Framtid 1944:4, s. 4I. Jfr även Artur Lundkvist, "Om författarskapets dekadans", Samtid och Framtid 1944:4, s. $2 \mathrm{I} \mathrm{f}$.

66. Olsson, "Författarskapets dekadens", s. I46.

67. Ibid., s. I59.

68. Även i andra texter vid mitten av 1940-talet uppvisar Olsson en starkt självdissekerande hållning. Se Roger Holmström, Hagar Olsson och den växande melankolin. Liv och diktning 1945-1978, Helsingfors: Schildts 1995, s. I3. 
Det är inte orimligt att tänka sig att denna självrannsakan tedde sig angelägen i samband med att O1sson fyllde 50 år 1943. Hon tillägnades då en antologi, Hård höst. I förordet skrev Olof Lagercrantz att många "inför det nya världskriget" hade "tvingats till uppgörelse och avräkning med den idévärld, som [de] tidigare anslutit sig till. Inte alla av modernismens apostlar får behålla helgonglorian”. ${ }^{69}$ Det sammanfattar ganska väl vad som står på spel i "Författarskapets dekadens". Hagar Olsson utvärderar den modernism som inte levt upp till de löften som strålade i så starkt, utopiskt ljus på I920-talet. Hon talar om den som en "efterkrigsgeneration" som plötsligt förfallit och blivit till "en förkrigsgeneration". ${ }^{70}$ I kontrast till I930-talet, då hon trots allt uppbådade en viss optimism i "Mörka vägar", tvingas hon nu erkänna litteraturens nederlag. ${ }^{71}$ Upplevelsen av ett nytt världskrig förändrar hennes historiska berättelse: nu föreligger inte längre ett givet, historiskt brott eller år noll att utgå från. Med två världskrig kompliceras bilden av modernismens historiska frammarsch.

Som en del av rörelsen tvingas Olsson rannsaka sig själv, och gör sig dessutom till "representant för hela det krigstida författarskrået", så som Holmström påpekat. ${ }^{72}$ "Och jag själv då?” frågar hon och undrar, i en "stund av bitter självprövning", hur hon kunnat bli en isolerad "skuggfigur" efter att tillsammans med sina likar på I920-talet ha framstått som "framtidens härolder" eller "framtidens riddare" (och på I930-talet alltså som avantgardistiska arbetare i natten). ${ }^{73}$ Talet om sin egen generation som isolerade skuggfigurer kan jämföras med hur hon i Ny generation använde i princip samma terminologi ("isolerad", "en skugga av sig själv") i kritiken av I89o-talets författare. Nu tycks den modernistiska generationen ha gått samma öde till mötes. Här

69. Olof Lagercrantz,"Den karelska grundtonen”, Olof Lagercrantz et al. (red.), Hård böst. Debatt och värdering, Stockholm: Natur och Kultur 1943, s. I2. Modernismen kom under 1940-talet att anklagas för överdriven individualism, inte minst i samband med den svenska fyrtiotalistiska strömningen och den s.k. obegriplighetsdebatten. Se t.ex. Mats Jansson, Kritisk tidsspegel. Studier i I940-talets svenska litteraturkritik, Eslöv: Brutus Östlings Bokförlag Symposion I998, s. 15I-190 och Peter Luthersson, Svensk litterär modernism. En stridsstudie, Stockholm: Atlantis 2002, s. 94.

70. Olsson, "Författarskapets dekadens", s. I5 I f.

71. Se Svensson, "Hagar Olsson och 30-talets idévärld", s. 3r6.

72. Holmström, "Tiga eller tala?", s. I54.

73. Olsson, "Författarskapets dekadens", s. I47, I52, I54. 
går det nästan att utläsa en föreställning om ett slags återkommande dekadensschema för litterära generationer, som påminner om den cykliska kulturutveckling hon beskrev i "Mörka vägar".

Hagar Olsson konkretiserar jämförelsen av de olika litterära generationernas öden genom att berätta hur hon i Helsingforslägenheten hittade sina egna artiklar från första världskriget. Att de båda världskrigen haft avgörande betydelse för hennes självförtroende och syn på modernismen och författarskap generellt blir uppenbart när hon skildrar hur hon följde sin "egen själs väg mellan de två världskatastroferna". ${ }^{74}$ Men även mer strukturella samhällsförändringar lyfts fram som en viktig orsak till att författarrollen måste omprövas. Olsson skriver att författarna tycks ha blivit obetydliga i den epok hon finner sig leva i, en tid där "massorna" och "tekniken [...] lägger gudarnas åskvigg i händerna på vem som helst". ${ }^{75}$ Framför allt menar hon att demokratin blivit sviken av författarna och de intellektuella, med en hänvisning till Julien Bendas klassiska verk från mellankrigstiden om "klerkernas förräderi" ${ }^{76}$ Olssons essä kan rentav betraktas som en sentida parallell till Bendas verk i finlandssvensk tappning.

Kollektivismen som den unga Hagar Olsson förespråkade tycks inte längre oproblematisk. Uppgiften att göra en avantgarderörelse som modernismen engagerad och tillgänglig för bredare samhällslager har uppenbarligen inte genomförts friktionsfritt. Kärnan i programmet Olsson nu formulerar mot erfarenheten av andra världskriget och totalitarismen är att "ingen verksamhet [...] kan betraktas som opolitisk och fritagas ansvar för det hela”. Detta, att allt har en politisk dimension och kräver ansvar, ser hon som "demokratiens väsen". ${ }^{77}$ Hon menar att författarna på ett mer ansvarsfullt vis hade behövt

74. Ibid., s. I49, I58. I "Jag lever" skriver hon även om hur atombomben och förintelsen berörde henne djupt. Se Hagar Olsson, "Jag lever'. En studie i det mänskliga", Hagar Olsson, Jag lever, Stockholm: Natur och Kultur 1948, s. I4-20. Jfr Wegelius, Civilisation kontra inre människa, s. I9, 87 .

75. Olsson, "Författarskapets dekadens", s. I53, I6 i f.

76. Ibid., s. 158 f. Se även Julien Benda, La trabison des clercs, Paris: Grasset 1927. Det har framhållits som tidstypiskt att författarna tecknas som svekfulla narrar vid tiden för andra världskriget. Holmström lyfter fram Pär Lagerkvists Dvärgen (1944) som ett exempel. Se Holmström, Hagar Olsson och den öppna horisonten, s. 35 I.

77. Olsson, "Författarskapets dekadens", s. I6 I f. 
stå bakom sina idéer och aktivt göra uppoffringar. Ska litteraturen ha berättigande och angelägenhet i demokratins tidevarv krävs "den yttersta insatsen av vår personlighet". ${ }^{78}$ Olsson efterfrågar alltså ett demokratiskt engagemang som grund för författarens legitimitet, i ungefär samma skede som la littérature engagée fick sitt stora internationella genombrott.

Som Holmström helt riktigt har understrukit, skärptes således Olssons etiska krav på författarrollen under andra världskriget. ${ }^{79}$ Intressant i det här sammanhanget är att hennes propagering för ett större individuellt ansvar hos författaren uppträder parallellt med att hennes essästil blir betydligt mer personlig. I enskilda stycken kan hon nu referera till sig själv i första person tio gånger. Som vi sett utgår inledningsscenen från hennes eget liv och är tydligt situerad i tid och rum. Hon använder retoriskt sig själv för att ge essän konkretion och kraft och konstruerar på så vis ett författarjag som inte alls förekommer på samma sätt i de två tidigare essäerna. Desillusionen som är en följd av modernismens misslyckande med att leva upp till sina egna ideal tycks få som konsekvens att hon inte längre vill hålla sig i bakgrunden och rida på rörelsens framgångsvåg. Den historiska utvecklingen och modernismens plats däri betraktas inte längre som lika självklar och författarna måste ta personligt ansvar och skarpt avstånd från l'art pour l'art. Retoriskt gör hon själv detta i texten genom att skriva fram ett tydligt jag som rannsakas. Hon genomför på så vis en korsfästelse av sig själv som författare i hopp om att ge författaren i allmänhet nytt liv, ty det var Olssons övertygelse att författaren behövdes för att rädda människorna från samtidens kris ${ }^{80}$ Hennes symboliska uppoffring kan därmed ses som den sorts expressionistiska handling (med

78. Ibid., s. I55 f. Vad gäller författarens uppoffring efterfrågar Olsson t.ex."den 'korsfästelse' som är konstens mysterium och gör den berättigad även i tider av stora lidanden". Se Olsson, "Författarskapets dekadens", s. I7ı.

79. Holmström, "Tiga eller tala?", s. I55.

8o. Här kan tilläggas att "självuppgivelse i kollektivismens tecken" har identifierats som ett centralt motiv i Olssons författarskap. Merete Mazzarella menar t.ex. att Olssons bästa verk fötts ur en "spänning mellan viljan till självuppgörelse och jagiskhet". Se Merete Mazzarella, Från Fredrika Runeberg till Märta Tikkanen. Frihet och beroende i finlandssvensk kvinnolitteratur, Helsingfors: Söderströms I985, s. 94, II7. 
utopisk potential) som Olsson, enligt Meurer-Bongardt, menade att dikten borde utföra. ${ }^{81}$

\section{SJÄLVKONSTRUKTION OCH OMVÄRDERING}

På I940-talet framstod det som viktigare än tidigare för Hagar Olsson att skriva fram sig själv som aktör. År 1925 kunde man av hennes deterministiska tongångar få intrycket att utvecklingen mot en ljus framtid var oundviklig så länge den styrdes av modernismens framtidsriddare. Olsson var redan i ett tidigt skede kritisk till vissa inslag $i$ modernismen, men de nya erfarenheterna av totalitarismen och andra världskriget fick henne att tänka om sitt litterära projekt i grunden. ${ }^{82}$ Så även om mycket i Hagar Olssons författarskap och litteratursyn utmärks av kontinuitet går det att se en intressant förändring över tid i hennes förhållande till modernismen. När tiderna blev mörkare förlorade hon sin tidigare övertro på modernismen. För att ge rörelsen legitimitet tillförde hon under i930-talet det modernistiska författarskapet en ny kvalitet genom att betona att modernisterna var som viktigast $\mathrm{i}$ just mörka tider, då de skulle verka som arbetare $\mathrm{i}$ natten. Hur hon anpassade modernismen och författarskapet utifrån det förändrade samtidsläget syns tydligt i de bilder och metaforer hon använder. Stilen och lyhördheten inför samhällsförändringarna införlivades i hennes strävan att ge modernismen legitimitet.

Att Olsson senare omvärderade sitt förhållande till modernismen behöver förstås inte bara bero på desillusion, utan kan även förklaras av att modernismen faktiskt hade etablerats allt starkare i ett finlandssvenskt sammanhang så att hon inte längre behövde strida för den på samma sätt som tidigare. ${ }^{83}$ Desillusionen över denna nya författargeneration var dock, som vi har sett, tydlig när hon på I940-talet publicerade "Författarskapets dekadens". Efter första världskriget tycks modernismen ha fyllt en viktig funktion som ett redskap för att lämna en föråldrad värld därhän. Första världskrigets katastrof kunde hon tämligen obehindrat förpassa till det förflutnas grav tillsammans med

8I. Meurer-Bongardt, Wo Atlantis am Horizont leuchtet, s. I24.

82. Holmström har t.ex. visat att hon redan under 1920-talet kritiserade delar av modernismen på kontinenten. Se Holmström, "Det självverksamma ögat"', s. 8 f.

83. Holmström, Hagar Olsson och den öppna horisonten, s. 165. 
traditionen. Men när andra världskriget inträffade i den värld som hon och hennes likar bara 20 år tidigare hade planerat att forma blev hon desto mer nedtyngd. ${ }^{84}$ Att återigen lyfta fram modernismen som framtidens härold var knappast ett alternativ. I stället var Olsson i det här skedet tillbakablickande och skärpte kravet på författarens personliga ansvar och sociala engagemang. Att vara del av en kollektivt inriktad modernism var inte tillräckligt; varje enskild författare måste finna en väg för att nå ut och därmed undvika att bli en "skuggfigur" instängd på kammaren. Nu blev hennes självkonstruktion en strategi för att ge essän diskursiv kraft. I stället för att lägga tyngdpunkten på modernismen argumenterade hon med hjälp av sin egen persona och förtätade bilder ur sitt eget liv, vilket givetvis kan bero på att hon som 50-årig, uppburen författare såg sig ha mer personlig auktoritet att ta spjärn emot jämfört med tidigare. ${ }^{85}$

Per Erik Ljung har, i sin avhandling om hur Vilhelm Ekelund brottades med författarrollen, menat att författares önskan att engagera sig socialt har varit ett centralt problem i modern tid eftersom litteraturen starkare etablerats som en autonom institution. De avantgardistiska rörelserna vid tiden för första världskriget kan därmed ses som ett uppror bland de författare som inte accepterade rollen de tilldelades enligt uppfattningen om litteraturen som autonom. ${ }^{86}$ Hagar Olssons protest mot l'art pour l'art i Ny generation är möjlig att tolka som en del av denna vidare rörelse. Men kanske var det först med "Författarskapets dekadens" som hon hittade ett effektivt sätt att konkret gestalta den engagerade författarens frigörelse från den autonoma sfären, genom en mer grundläggande problematisering av författarrollen och betoning av författarens ofrånkomliga demokratiska ansvar?

84. Här bör dock tillfogas att hon några år senare i essän "'Jag lever"' (I948) på nytt uttrycker en optimistisk tro på konstens och litteraturens framtidsmöjligheter. Se Wegelius, Civilisation kontra inre människa, s. Io4 f.

85. Agneta Rahikainen konstaterar t.ex. att modernismen under I940-talet var etablerad och att Olssons samtidigt åtnjöt stor respekt för sin position. Se Agneta Rahikainen, "Sierskan, huldran och den ständigt döende poeten. Hagar Olssons Edith Södergranbilder", Nordisk tidskrift för vetenskap, konst och industri, 91:2 2015, s. I37.

86. Per Erik Ljung, Vilhelm Ekelund och den problematiska författarrollen, Lund: Liber Läromedel I980, s. 24 . 
Den tidigare forskningen har rätt i att idealet l'art pour l'art är Hagar Olssons ständiga motståndare. Här har jag velat visa på nyanser i detta genom att undersöka hur den är det på aningen olika sätt, särskilt som hon på I940-talet fann sig själv och modernismen stående mitt i fiendeleden. Därmed hoppas jag ha givit konkretion till den förskjutning i Olssons förhållande till modernismen som Holmström tidigare påtalat, och som jag vill framhålla som en mer djupgående förändring eftersom Olsson i slutändan gjorde en stark omvärdering av författarskapets villkor och modernismens historiska roll. Precis som Holmström påpekat tenderar författarroller att särskilt sättas på prov i tider av krig och stora samhällsförändringar, vilket min läsning av Olssons essäer från I920- till r940-talet ger stöd för. Krigsårens påverkan på den finlandssvenska litteraturen har berörts i tidigare forskning. ${ }^{87}$ Olssons nya förhållningssätt till modernismen kan ses som ett ovanligt intressant exempel på hur synen på litteratur och dess samhällsroll omförhandlades i detta skede. ${ }^{88}$ Litterära rörelser behöver alltid legitimeras i relation till samhällets skiftande förutsättningar. I olika faser i en större omförhandlingsprocess presenterade Olsson modernismens författare först som framtidsriddare och sedan som avantgardistiska nattarbetare, för att slutligen, i samband med

87. Se t.ex. Erkki Sevänen \& Risto Turunen,"Från krigstid till ny normalitet", utg. Clas Zilliacus, Finlands svenska litteraturhistoria. Andra delen: rgoo-talet, Helsingfors: SLS 2000, s. 226-233 och Inga-Britt Wik, "Finlandssvenska krigsmodernister. Om Solveig von Schoultz, Mirjam Tuominen och Eva Wichman”, Elisabeth Møller Jensen (red.), Nordisk kvinnolitteraturhistoria. Vida världen Igoo-I960, Bd 3, Höganäs: Bra Böcker 1996, s. 513 f. Som Wik påpekar kom den andra vågens kvinnliga finlandssvenska modernistiska författare också att påverkas starkt av kriget som "ändrade villkoren för deras författarskap" så att de på olika sätt sökte "nya uttrycksmedel för sina erfarenheter". För Olsson, som tillhörde första vågen, resulterade krigserfarenheten framför allt alltså i en rannsakan och omvärdering av den modernism hon tidigare sett som en så oemotståndlig framtidskraft. För andra exempel på hur kvinnliga författarstrategier utvecklades under andra världskriget, se t.ex. Gill Plain, "Women Writers and the War", Marina MacKay (ed.), The Cambridge Companion to the Literature of World War II, Cambridge: Cambridge University Press 2009, s. 165-178, https://doi.org/ro.IoI7/CCOL9780521887557.013 (hämtad Io/5/2018).

88. För fler exempel (främst ur ett brittiskt perspektiv) på hur modernismen svarade på erfarenheter av krig och våld i samband med första och särskilt andra världskriget, se Marina MacKay, Modernism and World War II: Cambridge: Cambridge University Press, 2007 och Marina MacKay, Modernism, War, and Violence, London: Bloomsbury Academic 20I7. 
en självrannsakan, skildra dem kritiskt som isolerade skuggfigurer, i behov av ett nytt samhällskontrakt.

Hagar Olsson strävade ständigt efter att nå ut som författare. Att hon företog en så genomgripande självrannsakan vittnar om att hon själv inte förlorade världen ur synfältet. Rollerna som framtidsriddare och nattarbetare må hon ha iklätt sig själv i olika skeden, men någon isolerad skuggfigur, det var aldrig Olsson. Även om historien tycktes upprepa sig så ville hon inte utan vidare underkasta sig dess cykler. Hagar Olsson försökte åstadkomma förändring och skriva fram ett nytt förbund mellan författaren och samhället. 